\title{
Use of Strain-life Models with Wavelet Bump Extraction (WBE) for Predicting Fatigue Damage
}

\author{
Shahrum Abdullah', Choi Jae-Chil2, John R. Yates ${ }^{3}$ and Joseph A. Giacomin ${ }^{3}$ \\ 'Jabatan Kejuruteraan Mekanik dan Bahan, \\ Fakulti Kejuruteraan \& Alam Bina, \\ University Kebangsaan Malaysia \\ 43600 UKM Bangi, Selangor, \\ Malaysia \\ ${ }^{2}$ Hyundai Motor Company, \\ South Korea \\ ${ }^{3}$ Department of Mechanical Engineering, \\ University of Sheffield, \\ United Kingdom
}

Received Date: $28^{\text {th }}$ August 2006 Accepted Date: $7^{\text {th }}$ March 2007

\begin{abstract}
This paper presents the use of strain-life fatigue damage models to observe the cycle sequence effects in the wavelet-based fatigue data editing algorithm. This algorithm is called Wavelet Bump Extraction (WBE), which was developed to produce a shortened signal by extracting fatigue damaging events from the original signal with the retention of the original cycle sequences. Current industrial practice uses the Palmgren-Miner linear damage rule to predict the fatigue life or fatigue damage under variable amplitude (VA) loadings. Using VA loadings, however, this rule does not have load interaction accountability in the analysis. Thus, a more suitable approach has been identified for predicting fatigue damage of VA loadings, i.e. the Effective Strain Damage (ESD) model. In this study, the cycle sequence effect observation was implemented in both analytical and experimental works using the WBE extracted VA loadings. The study includes the comparison between the experimental and the analytical (using four strain-life fatigue damage models: Coffin-Manson, Morrow, Smith-Watson-Topper and ESD) fatigue damage. The smallest average in the fatigue damage difference was found when using the ESD strain-life model, suggesting the suitability of the this model for analysing VA fatigue loadings.
\end{abstract}

Keywords: Fatigue, variable amplitude, WBE, cycle sequence effects, ESD Model.

\section{ABSTRAK}

Kertas kerja ini membincangkan penggunaan model terikan-hayat lesu untuk mengkaji kesan jujukan kitaran dalam algoritma penyuntingan data lesu berasaskan teori gelombang-isyarat. Algoritma ini yang dikenali sebagai Wavelet Bump Extraction (WBE) diguna untuk menghasilkan suatu isyarat terpangkas iaitu dengan 
memilih hanya isyarat dari peristiwa lesu bermagnitud musnah daripada gelombang isyarat asal dan di samping itu, mengekalkan jujukan kitaran isyarat asal pada isyarat yang terhasil. Amalan industri masa kini menggunakan kaedah linear Palmgren-Miner bagi meramalkan jangka hayat lesu. Akan tetapi kesan jujukan kitaran yang wujud dalam kes lesu bebanan amplitud berbagai tidak diambil kira dalam kaedah tersebut. Justeru itu, model terikan hayat lesu Effective Strain Damage (ESD) yang mempertimbangkan kesan jujukan kitaran dirasakan lebih sesuai untuk digunapakai.Dalam kajian ini, pemerhatian terhadap kesanjujukan kitaran dilakukan secara analitik dan eksperimen dengan menggunakan isyarat beban yang terhasil daripada WBE. Perkadaran jangka hayat lesu dari keputusan eksperimen dibandingkan dengan keputusan analitikyang menggunakan empat model terikan-hayat yakni Coffin-Manson, Morrow, SmithWatson-Topper dan ESD. Ramalan model ESD memberikan bandingan perbezaan purata hayat lesu yang terkecil, menunjukkan kesesuaian model ini dalam analisis lesu beban amplitud berbagai.

Kata kunci: Model terikan-hayat lesu, amplitud pelbagai, algoritma Wavelet Bump Extraction, kesan jujukan kitaran beban amplitud berbagai, model Effective Strain Damage.

\section{INTRODUCTION}

Fatigue life prediction is important in the design process of vehicle structural components, with the essential input variable for fatigue is the load history. Practically, automobile manufacturers go to great lengths to instrument vehicles and subject them to a variety of driving conditions. By necessity, vehicle development requires accelerated fatigue testing and this is often accomplished by correlating test tracks with public road data. Both roads and test tracks generate variable amplitude (VA) load time histories. Loads that are predicted to do little or no damage can be eliminated and large amplitude cycles are retained. The process can be performed using a wavelet-based fatigue data editing, known as Wavelet Bump Extraction (WBE) algorithm which was developed by Abdullah et al. $(2003 ; 2004)$ with the retention of the loading cycle sequences.

The situation where the order of loading affects the fatigue life is called a sequence effect. Sequence effects exist both in the crack initiation stage and crack propagation stage (Fuchs and Stephens 1980). Sequence effects are also related to overload and underload condition in VA loadings (DuQuesnay et al. 1993; Topper and Lam 1997). When overloads were inserted in the small cycle or below the material fatigue limit, the small cycles following the overloads contributed to the fatigue damage accumulation.Considering the importance of sequence effects in the fatigue damage prediction under VA loadings (Dowling 1999), therefore, a suitable approach was introduced (DuQuesnay et al. 1993) in order to have closer fatigue life predictions when compared to the respective experimental findings.
In this paper the cycle sequence effects are analysed using the VA loadings extracted by the WBE algorithm. The analytical fatigue lives using four strain-life models were compared to experimental findings in order to observe the load interaction effects in fatigue damage prediction. To date, there are no current studies that are related to the analysis of cycle sequence effects using the loadings extracted from fatigue data editing algorithms. This paper, finally, discusses one of the stages for validating the WBE effectiveness, i.e. fatigue cycle sequence effects observation.

\section{BACKGROUND OF THE WAVELET BUMP EXTRACTION (WBE) ALGORITHM}

The Wavelet Bump Extraction (WBE) algorithm was designed to identify and extract fatigue damaging events in order to produce a shortened loading. This shortened loading should have equivalent fatigue damage and global signal statistical values to the original input loading. Using WBE, large amplitude segments were extracted with the retention of the original load cycle sequences. WBE has three main stages (Figure 1): the wavelet decomposition process, the identification and extraction of the fatigue damaging events, and the production of a mission signal.

WBE uses the orthogonal wavelet transform by means of the 12th order Daubechies wavelets which were chosen as the basis functions. Each wavelet level describes the time behaviour of the signal in a frequency band. Using the WBE algorithm, fatigue damaging events are identified in wavelet groups. A wavelet grouping stage permits the user to cluster wavelet levels into a single region of significant signal vibrational energy. 